\title{
Shall the Religious Inherit the Earth? - A Thought-Provoking Look into the Future of Faith
}

\author{
EMMA TERAMA, Ph.D., Senior Researcher \\ Finnish Environment Insitute and University College London
}

Media discourse in continental Europe, UK and even the Nordic countries has long revolved around a majority-minority divide stemming from population dynamics related to migration. A stream of immigrants to the Global North from overseas has been under much scrutiny over the past decades. Religion is thought to be one characteristic causing separation between "us" and "them".

It takes time to discover what shape the interplay between the immigrant and the native population takes. As minorities grow in size they become more visible in the community. Growth of the minority through demography or further in-migration provides the existing immigrant population with support for cultural identity and safety-nets. The native population may start to feel threatened as the "others" become more accustomed and relaxed in their new environment.

Not entirely unrelated, religion and migration issues are often bundled together in public discourse. However, some of the consequences of religion-related differentials have been a distinct part of (European) society for a long time, take for instance the catholic-protestant divide. The question is, how will the changing face of religious climate in Europe stir up the latent tensions of the past, or will it?

This is a good time to consider the current population and religious climate. The rightwing is taking over political seats in the parliamentary West, causing immigration policies to harden in several countries with a past of liberal attitudes and admissions. The most recent elections where this trend manifested itself took place in Finland, where the True Finns party won over several seats from the governing Centre parties. The winning slogans were mainly populist and nationalist by nature, and opposed to not only the EU membership in general, but to any flexibility in immigration matters and current quotas.

Eric Kaufmann (2010) relates to the threat of the "other" very well in his book 'Shall the religious inherit the Earth - Demography and politics in the twenty-first century'. What is interesting, is his juxtaposition of one so-called otherness with another, namely the Islamic faith with respect to the Christian faith, and religious fundamentalism with respect to the moderates/sceptics of any religion. In the book it is essentially argued 
that the rivalry between Christians and Muslims, even on European soil, is turning into a demographic competition between the "faithful" and the "faithless", namely the conservative branches of faith and the more secular. He refers to several pro-natalist fundamental or otherwise deeply conservative religious branches affiliated with Christianity, Islam or Judaism and accounts for their recent history in terms of size, political influence or power and trends in demography.

In Europe the most visible trend after on-going secularization ${ }^{1}$ seems to be that of the rise of fundamental Christianity. An example of fundamental, or conservative Christians in Europe is provided by the Laestadians, most of which can be found in Finland (Terama 2010). Kaufmann also mentions the Dutch Orthodox Calvinists, although comparing to the Laestadian population dynamcis, calls them a "milder version". Fundamental Christianity has world-wide proportions, however in the existing market-driven, neoliberal environment of Europe it creates perhaps the most striking contrast. In Erik Kaufmann's words "the moderate middle is being sqeezed out". For the European woman, it makes as much difference for childbearing (or more) to be religious as it does to have a high education, with opposite effects (Kaufmann 2010).

The protestant work ethic vocalized by Max Weber in 1930 may have shifted the balance of power inside Europe from the Catholic to the Protestant in the early 1900 , however these days most Europeans not only pray less, but also work less than the Americans (Alesina 2005). In the United States the rise of women's liberation and consumerism at the time of the "retreat of the sacred" further from public life, have fuelled the rise of fundamentalism, according to Kaufmann. In Springfield, Missouri there is approximately one church per every 1000 inhabitants, and altogether some 380 Christian places of worship to choose from (USA Church 2011). In addition to the superior church-going rates, the Americans have above all a greater conservative religious class. Kaufmann (2010), however mentions that the mainstream in this class is clearly more neo-evangelical than fundamentalist, and that the explosive growth of the Amish and the Mormons helps explain the rise of the evangelical Protestants in the last half-century, namely differential fertility.

A more dramatic effect of religious rise than growth through pro-natalism is achieved through immigration. Also called the third demographic transition (Coleman 2006), it is prognosed that the current wave of immigrants to the North will attribute to the rising share of non-white Europeans, constituting up to a quarter by 2050 (Kaufmann 2010). In the Eurostat report on migration based on 2006 statistics, over half of all people (re)settling in the EU-27 came from outside of the EU, and Moroccans were the majority (Herm 2008). Out of European nationals, Poles and Romanians were the

1 France and Scandinavia (let's include Finland) having started their secularization earliest, already in the $19^{\text {th }}$ century, have a steady church attendance rate of about 5 per cent (Kaufmann 2010) and have most likely completed their "secular transition". Secular "growth" still takes place in the more Catholic parts of Europe. 
most numerous settlers. Most immigrants are more religious (meaning more likely to actively practice their religion) than their secular, non-church going hosts. In London, for example, the group of Christians attending Sunday service is predominantly nonwhite at 58 per cent, while a sizeable portion of the rest are equally non-native, mainly from East Europe (Kaufmann 2010). In the rest of the country Christian attendance rates plummeted by 40 per cent between 1989 and 2005, whereas in London the high immigration numbers and their fertility ensures en masse church going according to Kaufmann. Somewhat similarly in the United States, immigration translates into a religious future of stagnating seculars and thriving (Hispanic) Catholics, who are on an upward trend that puts all other denominations "in the shade" (Kaufmann 2010).

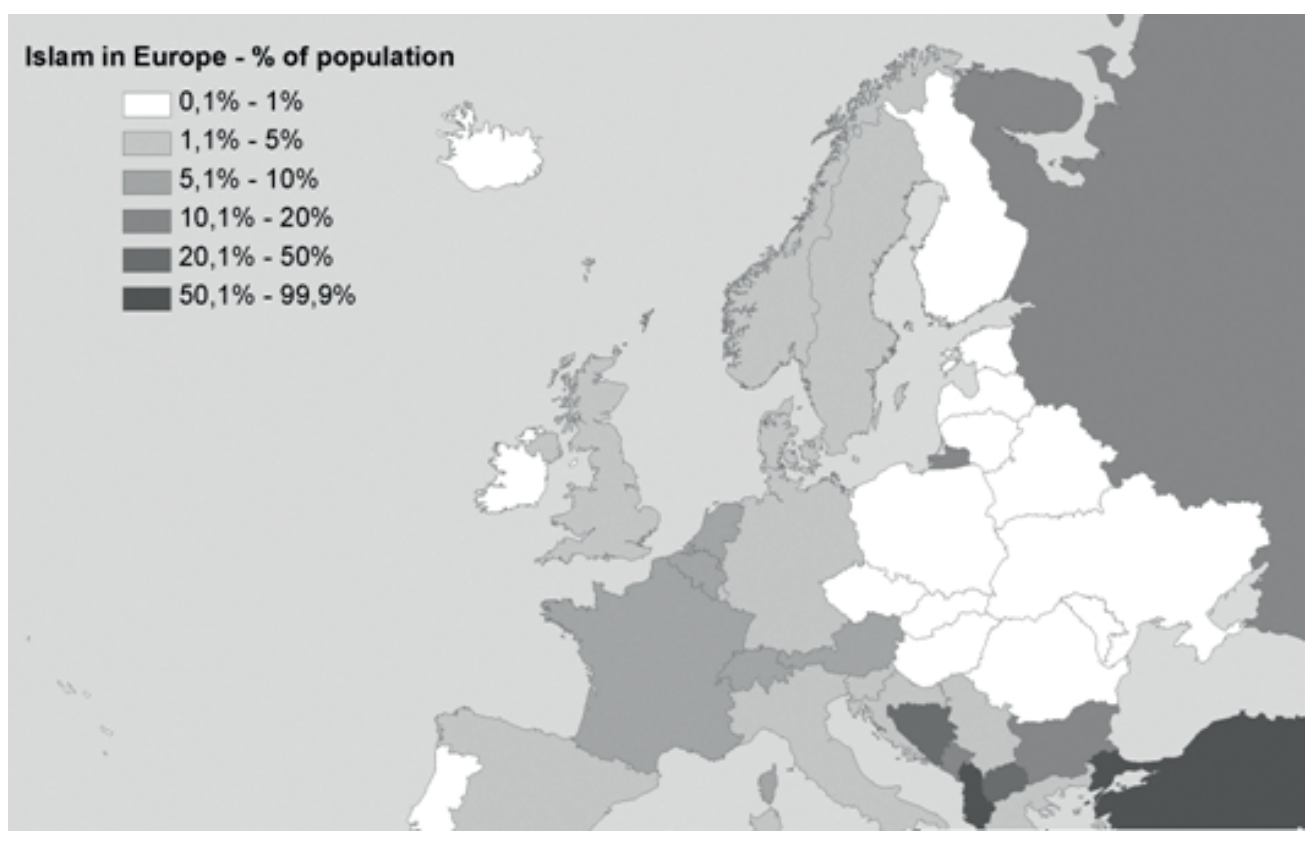

Map 1. Islam in Europe in 2010. Percentages: Skirbekk et al. (2010).

Despite the Eurabia-map being colored increasingly green on Wikipedia (2011), it remains a fact that most of Euope is only up to 5 per cent Muslim, see Figure 1 [map]. The average hue of green remains thus lighter than the walls of an operating theatre. The facts, however, sometimes escape the political parties vigorously opposing migration as a source of "otherness" in their societies. In the April 2011 parliamentary elections of Finland ( $<1 \%$ Muslim) the counter-immigration, anti-EU policy (to name a few) of the forementioned nationalist \& populist party was greeted by the public with overwhelmingly strong support that came as a surprise to the political elite and analysts alike. The party increased their number of seats in the national parliament six-fold from just five to 39 out of the total 200. 
Estimating Euope's Muslim stream of migrants at $1 / 4$ of a million per year, or 0.5 per cent of population is still a long way from the American example of Latin influence, where for several decades an influx equalling about 1 per cent of the American population has had a permanent impact on the demography of the nation (Kaufmann 2010). Recent projections on European and world Muslim populations (Skirbekk et al. 2010) attest to the fact that the European example is nothing like the influence and proportions of the American Hispanics. This is partly due to the fact that Muslim immigrant fertility, albeit high close to the time of migration (partly due to the often remote and rural areas of departure in the home country), seems to converge to the native population's fertility sooner or later. Migration laws have also tightened considerably recently, which causes a smaller influx of migrants. What is nevertheless true is that the difference in fertility of more and less religious mothers persists, also in the case of Muslims. This will in turn "power an erosion of secularism and moderate religion" as Kaufmann (2010) puts it.

Kaufmann stipulates further that the fear of "otherness" or exotic strangers is not so much fear of religious doctrines but a fear of a minority breeding the majority "into submission". This kind of threat "in the air" will no doubt eventually translate into political activism to increase or promote nationalistic ideals among constituents, as just happened in Finland. Kaufmann mentions similar political shifts having taken place in Norway, Italy and Austria, where blatantly offensive language and images are even used in marketing the ideals of the far-right parties at the wake of elections.

Not everyone is lured by the populist-nationalist agenda. The better educated, liberal or socialist European is typically unsupportive of the right-wing message. Left-wing parties are often the choice of their Muslim brothers and sisters, albeit the non-European immigrant has typically more conservative social attitudes. Despite receiving their vote, the left-wing parties e.g. in Flanders, Belgium do not openly court the Muslim electorate in fear of alienating the anti-immigrant vote (Kaufmann 2010). This may translate into political parties having to do the "electoral calculus" again, based on not only ethno-nationalist concerns but regional make-up of the electorate. An example is provided by Antwerp where the socialist share of votes increased from 19 to 35 per cent backed by the local Muslim population at the same time as the anti-immigrant Vlaams Belang-party stagnated due to the overall decline of whites in the population (Kaufmann 2010). The growth of the non-white electorate may therefore not induce a direct increase of the anti-immigrant vote.

In the book "Shall the religious inherit the Earth?" Kaufmann proposes as a solution to the immigrant-anti-immigrant electorate problem new coalitions down ecumenical, rather than ethnic or religious lines, powered by the degree of religiousness. It is easier, after all "to trumpet a morally than a racially conservative message" (Kaufmann 2010). He adds that this has long since been realized in American politics. 
The author then turns to look at the current state of affairs in Israel, where demographers have attested to the levelling off in fertility differences between the Muslim and the Jewish population. Youssef Courbage refers to the converging fertility behaviour (Jewish mothers closing the gap on the Muslims) as a "war of the cradles" (Courbage 1999). He would also prefer the notion of a "convergence of civilizations" rather than a "clash of civilizations" (Huntington 1996) considering the current understanding of the historical, social and demographic indicators (Courbage 2011).

What comes to the particulars concerning the convergence of the fertility behaviour in Israel, Kaufmann points out the rising minority of ultra-Orthodox, or Haredi Jews. Haredi sects grew out of 19th-century movements aimed explicitly at revitalizing and propagating theologically conservative Judaism and deterring secularization and conversion. They prefer to live in seclusion from the mainstream society, or where this is not possible, form their own neighbourhoods where strict Haredi laws of conduct are in effect. Interestingly, they have created such a political and consumption power lately that even brand product marketing and public spaces must abide to their standards, from omitting any too liberal symbolism from wrappers or product posters to banning traffic on the neighborhood roads on Shabbat (Kaufmann 2010).

State support for the Haredim ranges from generous child allowances to financing religious yeshiva educational institutions (also full-time for adults), as well as exemptions from military service. In 1996 approximately 60 per cent of Haredi men between ages 25 to 54 went to yeshiva instead of being employed (Kaufmann 2010).

The Haredim, and thereby the proportion of religious Israelis is estimated to grow immensely in the next decades due to their total fertility rate (TFR) of well over 7, compared to the secular Jewish fertility of around or even below replacement level, 2.1 (Kaufmann 2010). The Haredim now account for seven to eleven per cent of Israel's population, and grow at an estimated annual rate of 4 per cent, which means faster expansion rates than either Israeli Arabs or the rest of Israel's Jewish population (Cincotta and Kaufmann 2009).

Identity is critical to religious vitality in the contemporary world, and these days diversity can lead to strength. This may explain the wide array of sects having sprung from the cores of Christianity, Islam as well as Judaism. Fragmentation of e.g. the Haredi has not lead to decreasing numbers. Indeed also the Finnish Laestadians belong to different sub-divisions. A greater array of religious choice and competition for religious purity may simply lead to a stronger group identity or pride that in turn reinforces group boundaries.

When spiritualism and patriotism is combined, we can expect the right-wing vote to increase in our society. Haredi growth is already nudging the central tendency of Israeli politics towards the right (Kaufmann 2010). Military service participation is 
encouraged despite the excemptions already in place. So-called Hesder programmes have been implemented to combine Talmudic study with military service. Also in Finland, despite the potentially conflicting spiritual and patriotic duties, practically all Laestadians complete their service in Finnish defence forces. This already attests to a certain degree of patriotism. What comes to the recent parliamentary elections, regions with highest Laestadian populations did share their formerly centre-driven vote with the newly force gathered right-wing party. Remains to be seen whether the potential for growth among the Laestadians will be translated into as much political power and influence as seems to be the case for the Haredi in Israel. At the moment the Laestadians occupy a very small share of the total population, still approximately twice that of the Muslims (Terama 2010).

In his book, Kaufmann goes on to explain why the more religious also act more conservatively at the ballot. He draws upon American examples of Democrat vs. Republican support, identifying cause and effect relationships such as Republicans addressing religious issues more, including support for faith-based schools (Kaufmann 2010).

Devout populations of any denomination seem today to be particularly resistant to decline. Many of them are endogenous growth sects encouraging large families, much alike the old days when a population's victory or demise was governed by the fertility of its women, and thus ability to grow its own military forces. Like Kaufmann (2010) puts it:

"As the growth of early Christianity shows, compound effects mean that even a small demographic advantage can lead to big changes over several generations."

Muslims will not take over Europe, writes Kaufmann, but instead will stabilize their proportions of the total population to around a fifth by 2100 , not that population projections spanning that far are particularly reliable. The liberal ideal of "Let[ting] a thousand lifestyles bloom" is probably not going to make the "final cut", however simply due to the fact that dry atheism simply cannot compete with religious fervor. What makes matters more challenging (for the seculars), is their demography. "Too little too late", one might say to the currently mildly increasing fertility levels in developed countries (Myrskylä et al. 2009) since atheist mothers still bear the least children of all. Kaufmann (2010) even finds evidence suggesting that "the religious live longer and are happier than sceptics".

\section{Acknowledgements}

The author would like to thank the Academy of Finland for funding and Ville Helminen from the Finnish Environment Institute for Figure 1. 


\section{Bibliography}

Alesina, Alberto, Edward Glaeser and Bruce Sacerdote. 2005. Work and Leisure in the U.S. and Europe: Why So Different? NBER Macroeconomic Annual: 1-64.

Cincotta, Richard and Eric Kaufmann. 2009. The Changing Face of Israel. Foreign Policy. June 1.

Coleman, David. 2006. Immigration and Ethnic Change in Low-Fertility Countries: A Third Demographic Transition. Population and Development Review 32, No. 3:401-446.

Courbage, Youssef. 2011. Religion, Demography and Conflicts in Muslim Countries. Proceedings of the Population Association of America. Available online at http:// paa2011.princeton.edu/download.aspx?submissionId=112751 Last accessed May 12, 2011.

Courbage, Youssef. 1999. Reshuffling the Demographic Cards in Israel/Palestine. Journal of Palestine Studies 28 (4):21-39.

Herm, Anne. 2008. Statistics in focus: Population and social conditions. Eurostat 98/2008. Available online at http://epp.eurostat.ec.europa.eu/cache/ITY_OFFPUB/KSSF-08-098/EN/KS-SF-08-098-EN.PDF. Last accessed May 11, 2011.

Huntington, Samuel P. 1996. The clash of civilizations and the remaking of world order. Touchstone, New York.

Kaufmann, Eric. 2010. Shall the religious inherit the Earth? Demography and politics in the twenty-first century. Profile books ltd, London.

Myrskylä, Mikko, Hans-Peter Kohler and Francesco C. Billari. 2009. Advances in development reverse fertility declines. Nature 460:741-3.

Skirbekk, V., M. Stonawski, S. KC, and A. Goujon. 2010. The Future of the Global Muslim Population. Projections for 2010-2030. Pew Forum Report. Available online at http://www.iiasa.ac.at/Research/POP/pub/Skirbekk/ FutureGlobalMuslimPopulation-PEWreport.pdf Last accessed May 13, 2011.

Terämä, Emma. 2010. Regional Demographic Differences: the Effect of Laestadians. Finnish Yearbook of Population Research XLV, pp. 123-141.

USA Church 2011. Springfield Missouri church \& Christian school directory. Available online at http://www.usachurch.com/missouri/springfield/home.htm Last accessed May 13, 2011.

Wikipedia 2011. Eurabia. Available online at http://en.wikipedia.org/wiki/Eurabia Last accessed May 12, 2011. 